INÖNÜ ÜNIVERSITESI

HUKUK FAKÜLTESI DERGISi

\title{
ORDER ON MOTION TO DISMISS INDICTMENT
}

\section{Azem Hajdari}

Faculty of Law, University of Prishtina ñHasan Prishtinaò, Prishtina, Kosova, (gazem.hajdari@uni-pr.edu).ORCID: https://orcid.org/0000-0002-8426-4024

Albulna Hajdari

Faculty of Law, ILIRIA College, Prishtina, Kosova, (albulenahajdari@gmail.com). ORCID: https://orcid.org/0000-0002-3013-1576

\section{Article Info}

Received: $13 / 11 / 2018$

Accepted: 30/06/2019

\section{Keywords}

Order,

Motion to Dismiss,

Jurisdiction,

The Defendant,

Court,

Prosecutor.

\begin{abstract}
The object of this paper is a court order on motion to dismiss indictment in the Republic of Kosova. This order is a non-meritorious decision, by which the court dismisses the indictment because it lacks jurisdiction on procedural grounds. The order on the defendantôs motion constitutes a relatively common type of judgment rendered in criminal proceedings in Kosovo. This article will address such orders in several respects including the meaning of the order, its characteristics, grounds for dismissal and the authority to render it, as well as the procedure for and effects of reaching this type of verdict. To that effect, cases before the Basic Courts of Kosovo in which the defendantôs motion filed with the court asking the judge to throw out certain criminal charges during the proceedings in a period between 2015 and 2017 will be studied. The paper aims to foster the expectations that concrete actions should be taken to advance the performance of judges and prosecutors, highlighting the need to undertake a more effective vetting of public prosecutors and judges in the country. For this, there is an increasing support in local and international public opinion where the belief that Kosovo has already achieved a successful criminal justice system prevails. A legal, comparative, analytical and statistical methodology is used for the preparations of the present work.
\end{abstract}




\section{INTRODUCTION}

An order on motion to dismiss indictment (which we call, rejection judgment in this article) is a special court decision with which the criminal case is thrown out and the subject matter remains unresolved because the courts lacks jurisdiction to rule on the matter at hand. In Kosovo, the court issues such an order when a procedural barrier arises in the course of criminal proceedings. This kind of decision can be taken by the court from the moment of the opening of the main trial until its completion, if and when one of the legal deficiencies occurs. Reasons for filing a motion to dismiss criminal charges may include, inter alia, the existence of a final judgment on the same matter (res judicata), passing the statutory limitation of criminal prosecution, lack of subject matter jurisdiction or personal jurisdiction, failure to state a charge for which a punishment is sought, insufficient service of process and the withdrawal of the indictment by the state prosecutor etc. The order on motion to dismiss can be rendered by a criminal court judging the case at the request of the defendant who files the motion, but this can be done ex officio also. If it is a dismissal with prejudice, then the indictment is rejected, so that it does not address at all the merit of the case as to whether or not a criminal offence has been committed and guilt can be attributed to the accused. However, this is a formal judgment by which the court with some finality addresses legal costs, property claims, detention on remand and other measures to ensure the presence of the defendant in criminal proceedings (immediately terminates them). The concept of rejection judgement needs to be examined in both theory and practice. In this paper, the work of the Basic Courts of Kosovo during the period from 2015 to 2017 is examined to evaluate how orders on motion to dismiss indictment were delivered. Data is gathered to show how often and in what circumstances rejection judgements were delivered. Our study reveals some irregularities and thus makes recommendations on how to overcome them.

\section{THE NOTION OF THE REJECTION JUDGMENT}

One of the three types of judgments the court is authorized to render in criminal proceedings is a dismissal order with prejudice. This type of judgment manifests substantive, principled and concrete differences from the sentencing and the acquittal judgment. As such, it is different from these two types of judgments conceptually as well. Thus, while the conviction and acquittal judgments are considered meritorious judgments, the dismissal order is a non- meritorious judgment ${ }^{1}$.

The characteristic of the dismissal order is that this Judgment throws out the case and the subject matter of the trail remains unresolved. In these cases, the rejection of the indictment is due to the existence of a procedural obstacle $^{2}$.

The Criminal Procedure Code of the Republic of Kosovo does not make any definition of the notion of dismissal order (Criminal Procedure Code, Article 363). Nor was a concise definition of the notion of this type of judgment done by the science of the criminal procedure law in Kosovo. Consequently, we consider that in defining the notion of the dismissal order, all the elements that characterize this type of judgment will have to be taken into account. Therefore, in our opinion the order to dismiss is a court decision of a particular type with which the criminal case remains unresolved and in effect, the court judging the case takes it when a procedural barrier arises in the course of solving the criminal case.

\section{THE CHARACTERISTICS OF THE REJECTION JUDGMENT}

Like any act, namely a judicial decision (which specifically refers to a judgment) that has its characteristics, the rejection judgment also includes some specifics, which make it of a particular nature, different from any other judicial decision(s) (judgements). Consequently, as features of the rejection judgment, among other things, these should be considered:

\section{A. Existence of Procedural Obstacles in The Path of Solving The Criminal Case}

The most fundamental feature of the rejection judgment, which in fact determines the imposition of this type of judgment, is the existence of procedural obstacles which in the path of resolving the criminal case prevent the court from issuing a meritorious judgment (sentencing or acquittal judgment for the accused). Ascertaining the existence of procedural barriers is a factual matter of the court. Thus, when it is based on the notification of criminal procedural parties or when ex officio learns about them and verifies their existence in relation to the criminal case that is the object of the trial, then it essentially renders a rejection judgment. For such procedural obstacles to determine the rendering of the rejection judgment and to assume the epithet of one of its basic characteristics, pursuant to the Criminal Procedure Code of Kosovo (Article 363, paragraph 1, sub-paragraph 1.1), it is required that the courts to have learned in the time period from the beginning to the end of the main trial.

\footnotetext{
${ }^{1}$ The meritorious judgment is a verdict by which the criminal case is resolved, while with a non-meritorious judgment the criminal case remains unresolved (does not result in a finding of existence or not of the offense and guilt of the accused).

${ }^{2}$ SAHITI, Murati, Elshani, 2014, pg. 843. 


\section{B. FORMAL, NON-MERITORIOUS DECISION-MAKING IN THE SOLVING OF THE CRIMINAL CASE}

The rejection judgment in the theory of Kosovo's Criminal Procedure Law is considered a formal judgement. This means that it lacks the substantive effects that inevitably derive from the rendering of a sentencing or acquittal judgment. "These effects relate mainly to the accused, and they are a consequence of the court's decision regarding the existence or not of the offense and the accusation of the defendant in relation to himò ${ }^{3}$. Consequently, upon the imposition of the rejection judgment, the court is unable to issue any decision on the fact of whether or not the criminal offense has been committed and the guilt of the accused in relation to it. In such a situation, for many reasons, the court judging the case has been deprived of the possibility of merit-based decision-making on the subject matter of the trial. However, in the case of receiving such a type of judgment, in its enacting clause the court must describe the personal data of the defendant and the criminal offense for which it has rendered such a judgment. "This, with the aim of preventing the possibility of violating the principle ñNon bis in idemò ${ }^{4}$.

\section{Effective Decision-Making on Some Concrete Procedural Criminal Cases}

Despite the fact that the rejection judgment is a non-meritorious judgement, however, being a separate type of judgement that concludes a concrete criminal case, it also causes some effects, which in essence result from a formal, non-meritorious decision-making in solving the criminal case. "Consequently, with this kind of judgment, although it is not decided on the fact of whether or not the offense is committed and the accused's guilt, again by issuing it, some concrete decisions are taken, which although in essence are of a formal character, manifest concrete effects especially for the accused ${ }^{5}$ ò. Thus, when rendering on a rejection judgment, the court must decide on the costs of the criminal proceedings, the property claim (if such a request is made) by instructing the parties to refer the same to a civil litigation, releases the accused from detention on remand and removes other security measures that may have been imposed against him 6 .

\section{Criteria on The Basis of Which A Rejection Judgment May Be Issued}

On the possibility of imposing a rejection judgment it is referred in Article 363, paragraph 1 of the Criminal Procedure Code of the Republic of Kosovo. Through this legal provision, the Kosovar lawmaker has defined the criteria on the basis of which the court judging the case may issue such a judgment. Such criteria under this lawmaker are considered:

1. The State Prosecutor's Withdrawal From The K̦dictment From The Beginning Until The End of The Main Trial.

As is known the condition for the conduct of the court proceedings is the submission of the indictment by the institution of state prosecution. Since the indictment is an act of the state prosecutor, the lawmaker, even after it has submitted at the court, grants him the possibility to sway with it (stand by the filed indictment, amend it or withdraw it). Viewed in this regard, it is always expected that it will engage in the execution on the basis of the indictment. "However, in accordance with Article 52 of the Code of Criminal Procedure, the state prosecutor may withdraw from the prosecution until the end of the main trial in front of the basic court, but the partial or total withdrawal of the indictment or its amendment may also be filed before the Court of Appeals ${ }^{7}$.ò When the state prosecutor withdraws from the indictment from the beginning until the end of the main trial, the court issues a judgment rejecting the indictment. In these cases the state prosecutor's statement withdrawing from the indictment should be categorical and explicitly stated ${ }^{8}$. This is because the withdrawal of the indictment eliminates the legal basis for the continuation of the trial "nemo iudex sine actore". Certainly, the withdrawal of the state prosecutor's indictment from the beginning until the end of the main trial constitutes the basic criterion determining the rendering of the rejection judgment ${ }^{9}$. As will be seen below, this is the criterion that prevails in Kosovo's case law in cases where basic courts impose rejection judgments.

2. The Existence of A Final Judgment For The Accused For The Same Criminal Offense, Namely The Final Decision on The Dismissal of The Criminal Proceedings Relating to That Offense.

The contemporary legal system, including that of Kosovo, characterizes many institutes and principles which are in the function of creating legal certainty. "One of such principles is the principle" res judicata ", the principle prohibiting the re-trial of the same offense ${ }^{10}$. This principle, which has been elevated in the line of basic criteria that determines the imposition of a rejection judgment, has great legal value since it hampers the repetition of the

\footnotetext{
${ }^{3}$ Compare: FUNK, 2006, pg. 83.

${ }^{4}$ HAJDARI, 2013, pg.77.

${ }^{5}$ PAVIǴĹ, Vul kovil, VELIĹ, Radoloviĺ, 1998, pg. 321.

${ }^{6}$ HAJDARI, 2016, pg. 889 ï 890.

${ }^{7}$ SAHK̦I, Murati, Elshani, 2014) pg. 844, Article 303, paragraph 5.

${ }^{8}$ HAJDARI, 2016, pg. 889.

${ }^{9}$ HAJDARI, 2013, pg. 76 .

${ }^{10}$ SAHITI, 2013, pg.373.

Azem HAJDARK় Albulna HAJDARK,
} 
consequences of the application of court proceedings in relation to the accused but also for other reasons related to preservation of court authority, preventing public expenses, etc. Hence, the Kosovar lawmaker rightfully in Article 363, paragraph 1, subparagraph 1.2 of the Criminal Procedure Code has addressed the legal solution which obliges the basic court which has opened the main trial in any case when it finds that for the same criminal offense which is the subject of the trial, the defendant has been tried by a final judgment or the proceedings against him have been terminated by a final ruling, to issue a judgment rejecting the indictment.

3. The Expiration of The Statutory Limitation Period of Criminal Prosecution And The Knclusion of A Criminal Offense in The Act of Amnesty, Pardon or When There Are Other Circumstances That Exclude Criminal Prosecution

This is the third criterion, but of equal importance to the two above-mentioned criteria, the completion of which determines the issuing of the rejection judgment. This criterion consists of three bases that determine the issuing of the rejection judgment. The first refers to the existence of the institute of statutory limitation, the second existence of the institute of pardon and amnesty, while the third revealing some other circumstances the existence of which excludes criminal prosecution. While for the first two bases the issue is clear because the rendering of the rejection judgment is determined by the existence of two acts leading to the extinction of the offense (pardon and amnesty), which are regulated by special laws, thirdly, the legislator has created opportunities for legal confusion, because it has not specified the circumstances which need to be fulfilled and by which dictating the rendering of the rejection judgment. In this case, the responsibility was transferred to the court conducting the main trial regarding the concrete criminal case. "However, as in criminal law theory and judicial practice, as circumstances that exclude criminal prosecution are considered: a) death of the accused person, lack of age for criminal liability, lack of proposal for prosecution for the criminal offenses for which a proposal is sought ${ }^{11}$, ò lack of court jurisdiction to judge the concrete case, etc (Article 402, paragraph 1, point 1 of the Criminal Procedure Law of Macedonia).

Finally, it is worth pointing out that the rejection judgment should be issued, it is understood from the beginning to the end of the main trial, as soon as it is ascertained the existence of circumstances that hinder the criminal proceeding, namely once one or more of the criteria discussed above. It, as noted above, is issued with the request of the parties or mainly by the court.

\section{AUTHORITY TO RENDER A REJECTION JUDGMENT}

Issuing of judgments is the exclusive right of the court. Rejection judgment are no exceptions to this rule. Hence, the authority to issue the rejection judgment belongs to the court judging the case. Within the basic court, the authority for the issuing of the rejection judgment belongs to the single trial judge or the panel of judges. "The single trial judge or trial panel of the basic court in which the criminal case is conducted is legally obliged to issue a rejection judgment at any time when, from the moment of the opening of the main trial until its completion, it determines the fulfilment of one of legal requirements (criteria) ${ }^{12}$ ò set out in Article 363 of the Code of Criminal Procedure for which it has been discussed above. Rendering of a rejection judgment by the Basic Court is determined in the cases when a majority of the criteria are met or one of the criteria on the basis of which such a judgment can be issued. Ascertaining the fulfilment of such criteria is a discretionary issue of the single trial judge or trial panel. Consequently, in the case of the rendering a rejection judgment, the competent Basic Court concludes the criminal proceedings by not declaring at all about the existence or not of the offense and the guilt of the accused. However, it should be emphasized that, in any case, the closing of the criminal process through a rejection judgment should be made by specifying the fact of rejecting the indictment against the accused and by addressing some of the decision-makings mentioned above.

\section{THE PROCEDURE FOR RENDERING THE REJECTION JUDGMENT}

Generally, there is no substantial difference in terms of the procedural rules of rendering a rejection judgment, from the acquittal and sentencing judgments. Hence, it can be said freely that the principle rules for rendering the three types of judgements at the Basic Court are identical. In order not to avoid the specific requirements that are commonly referred to in the scientific publications, in addition to this article, only specific rules will be dealt with, essentially referring to the issuing of the rejection judgment, and will avoid the elaboration of standard procedural rules that they are accorded to all types of judgments.

As stated above, a rejection judgment can be rendered at any time starting from the moment of the opening of the main trial until its completion, when any one of the criteria set out by law is met for issuing it. In the case of this judgment, it is not required to administer the evidence and to establish the facts regarding the charges that are made to the accused for committing the criminal offense. Thus, it cannot happen with the acquittal and sentencing judgment. This means that these two types of judgments can be issued only when all evidence (especially decisive ones) referred to the concrete case has been administered at the main trial and the relevant facts referred to in that case have been established. Establishing the facts can be made in the context of establishing the accusation or even in a contrary context.

\footnotetext{
${ }^{11}$ ISLAMI, Hoxha, Panda, 2003, pg. 502.

${ }^{12}$ MARINA, Paj! il , 2016, pg. 31 ï 32.

Order On Motion To Dismiss Indictment
} 
Consequently, the initiative for issuing the rejection judgment may come from the parties or mainly from the court. Parties, for example, the state prosecutor sets in motion the court's action to issue a rejection judgment by withdrawing his indictment in respect of which the court has opened the main trial. Of course, the motion of the court to impose a rejection judgment can also be done by the defendant and his defence counsel (without excluding the state prosecutor) in cases of amnesty or pardon for criminal offenses for which the court has the main trial, but also for the fulfilment of other conditions e.g. for lack of age for criminal liability etc. The issue of rendering a rejection judgment can be addressed mainly by the court, when it itself learns of the existence of any legal criterion that determines the rendering of such a judgment, eg when it ex officio learns the existence of an amnesty or pardon etc. Once official information has been made by the parties, or after the court "ex officio" has learned of the fact of existence of any of the criteria which necessarily conditions the issuing of the rejection judgment, the subsequent obligation arises for the court judging the case that, after establishing the existence of such criteria, goes directly to the application of the procedural rules that finalize the fact of the rendering of such a judgment. Regarding the rendering of a rejection judgment, the court judging the case must notify the parties and other interested persons by public announcement and delivery its copies. They have the right, when considering such an unlawful or unjust judgment, to attack it by a special appeal, which should be addressed to the court that issued the judgment for the Court of Appeal.

\section{EFFECTS OF THE REJECTION JUDGMENT}

As in any judicial decision, even in cases of rendering a rejection judgment causes concrete effects that affect all kinds of interests. In the present case, some of the fundamental effects that arise in rendering this type of judgment will be discussed. Consequently, among the effects that arise when issuing a rejection judgment are mainly these:

\section{A. The Interruption of Continuation of The Main Trial is Determined in Order to Establish Whether The Allegations Raised Against The Accused Are True or Not}

As stated above, the Rejection Judgment eliminates any possibility to ascertain whether or not the criminal offense has been committed and also the guilt of the accused. "In the case of this judgement, the criminal case remains unclear, which for a part creates some uncertainty for public opinion, especially when that public opinion is well informed of the fact of the existence of the criminal offense and of the guilt of the accused ${ }^{13}$ o.

\section{B. The Accused Who is Detained is Released From Custody, ie Against Him Any Security Measures is Terminated That Was Imposed By The Court}

This favourable effect on the accused is immediate, regardless of whether he was guilty or not guilty for the offense with which he was charged.

\section{Clearly Determined to Address The Costs of Criminal Proceedings}

In the case of rendering the rejection judgement, the costs of the criminal proceedings, except for those caused by the fault of the procedure participants, fall under the responsibility of the state budget.

\section{The Issue of Property Claim is Addressed}

In case a property claim is filed from the injured party, the same cannot be solved by a rejection judgment. In the case of issuing such type of judgment for the accomplishment of such a request, the injured party is instructed for civil litigation.

\section{E. Some of The Public Spending is Reduced}

Upon the rendering of the rejection judgment, further development of the judicial review is eliminated in the context of proving the criminal case. Observing in this regard, depending on the moment of learning of the existence of procedural obstacles that determine the issuing of the rejection judgment, it results in a greater or lesser reduction of expenses for witnesses, experts, lump sum expenses etc.

\section{SOME DATA ON THE RENDERING OF REJECTION JUDGMENT}

Deriving to concrete conclusions and making consistent recommendations regarding the rejection judgment rendered by the courts, other relevant institutions and the society as a whole requires researching and studying the activity of the Kosovo courts, namely the Basic Courts for a certain period of time. In this case, the activity of these courts has been researched for a period of three years $(2015$ - 2017). I consider that the treatment of the rejection judgment, seen in terms of its rendering in practice for a period of three years, offers real chances that can be considered sufficient for the successful realization of such a goal. Presentation of the work of the Kosovo Basic Courts regarding the level, performance of the sentence rendering and other data and criteria regarding the rejection judgment was not an easy matter. This is due to the fact that with regard to the work of these courts, regarding these data during the research period there are no published statistics that can serve until the conclusion of this article. This 
situation conditioned the need that through the application of the sampling method to be involved in the elaboration of 100 rejection judgements obtained from all the Courts of the country. Despite this fact, the following treatment will initially present general data on criminal cases adjudicated by the Basic Courts of Kosovo for the period 2015 - 2017, involving adult and juvenile perpetrators of criminal offences, and the number of rejection judgments which these courts have rendered during this period of time ${ }^{14}$.

Table 1. The number of criminal cases tried and the rejection judgments imposed

\begin{tabular}{|l|l|lrl|}
\hline \multicolumn{1}{|c|}{ Time period } & \multicolumn{1}{|c|}{ Cases adjudicated } & \multicolumn{2}{c|}{ Rejection Judgments } \\
\hline 2015 - 2017 & Adults: 62311 & Adults: 4140 & \\
& Juveniles: 8239 & Juveniles: 00 & \\
\hline Total & & 70550 & & 4140 \\
\hline
\end{tabular}

According to these data, the Basic Courts of Kosovo during the period 2015-2017 regarding the indictment filed for the commission of various criminal offenses have adjudicated a total of 70550 persons, of whom 62311 were adults, while juveniles were charged with 8239. As the number of juvenile offenders judged is 54072 cases or $86.8 \%$ lower than the number of adult accused persons, which was basically expected, based on the fact that even in earlier periods the percentage of the presence of juveniles in committing criminal offenses was about $11 \%{ }^{15}$. These data point to the fact that the Basic Courts of Kosovo during the research period had issued a rejection judgment only in 4140 cases, and that exclusively to adult accused persons. Despite this, these courts during the research period have rendered more often sentencing and acquittal verdicts for the defendants, and have addressed other decision-making. Looking into this aspect, the sentencing judgment was rendered in 54655 cases (the most), while the acquittal judgment in 1882 cases. Meanwhile, other decisions (mostly in juvenile criminal proceedings such as: diversity measures, educational measures, mandatory treatment measures, etc.) these courts have addressed in 9873 cases. The fact that the courts in question have not issued any rejecting judgments against juveniles is currently an inexplicable matter. The used data prove that rejection judgments during the period covered by the research were mostly rendered by the Basic Court of Pristina in 1123 cases, and at least the Basic Court of Mitrovica in 234 cases. The cause of this situation in relation to the Basic Court of Pristina must, however, be related to the large number of cases that this court has at their disposal, which is conditioned by the fact that this court extends its activity to a territory in which more than $1 / 3$ of the Kosovo population lives ${ }^{16}$. Meanwhile, the cause of such a situation in relation to the Basic Court of Mitrovica should be related to the fact that this court until the beginning of 2017 has worked at a diminished capacity and in inappropriate settings.

Based on the fact that the data of the Kosovo Judicial Council and the Kosovo Agency of Statistics do not contain any information on what the criteria were based on which the Basic Courts of Kosovo have issued rejection judgments, the coverage of these data will be made based on the study of 100 judgments that these courts rendered during the research period (List of Basic Court Decisions). The findings of these judgments point to the fact that the basic courts of Kosovo in 54 cases have issued the rejection judgments due to withdrawal of the indictment by the state prosecutor from the beginning until the end of the main trial. In these 54 cases, in over $90 \%$ of them the withdrawal of the indictment was made because it was not possible to prove the defendant's charges that were charged with, whereas in other cases the indictment was withdrawn because of the withdrawal of the proposal for criminal prosecution by the injured party. On the other hand, in 19 cases the rejection judgment was rendered because of the acts (law and decisions) issued were covered by amnesty and pardon and in 27 cases due to the statutory limitation of the criminal prosecution. These data point to the fact of the presence of insufficient professionalism and an unsatisfactory update in the activity of the Kosovo judicial and prosecutorial system. Therefore, it is required by the institutional responsibilities to undertake concrete actions that enhance the performance of judges and prosecutors, including the necessity to carry out a vetting process in the entirety of bodies that constitute the criminal justice system in the country. This is due to the fact that in local and international public opinion prevails the belief that Kosovo has already crossed over to a seized justice system.

\section{CONCLUSION}

The modest results of this article have led me to the following conclusions:

1. One of the three types of judgments that the court is authorized to issue criminal proceedings is the rejection judgment. Rejection Judgment is a court decision of a special kind with which the criminal case remains unresolved, which the court judging the case issues when a procedural barrier arises in the course of solving the criminal case.

\footnotetext{
${ }^{14}$ Annual Reports of the Kosovo Judicial Council and Kosovo Agency of Statistics on the Work of Kosovo Courts for the period 2015 ï 2017.

${ }^{15}$ HAJDARI 2015, pg. 19 ï 20, HAJDARI, 2015, pg. 48 ï 49.

${ }^{16}$ Data on the Kosovo population from the Kosovo Agency of Statistics.

Order On Motion To Dismiss Indictment 
2. The rejection judgment includes certain features which make it of a particular nature, different from any other court judgment (verdict). As a characteristic, among others, the following are considered: a) The existence of procedural obstacles in the way of solving the criminal case. b) Formal, non-meritorious decision-making resolution of the criminal case; and c) Effective decision-making in relation to certain concrete procedural criminal issues.

3. A rejection judgment can be rendered only after the criteria for its rendering have been met. As criteria on the basis of which this type of judgment can be issued are considered: a) Withdrawal of the state prosecutor from the indictment from the beginning to the end of the main trial; b) Existence of a final judgment for the accused for the same criminal offense, respectively a final ruling on the dismissal of the criminal proceedings related to that offense, c) The expiration of the statutory limitation period of criminal prosecution and the inclusion of the offense in the act of amnesty, pardon or when there are other circumstances that exclude criminal prosecution.

4. The authority to render a rejection judgment belongs to the basic court judging the case. Within the basic court, the authority for the issuing of the rejection judgment belongs to the single trial judge or the panel of judges. The single trial judge or trial panel of the basic court under which the trial of the criminal case is conducted has the legal obligation to issue a rejection judgment at any time when, from the moment of the opening of the main trial until its completion, it determines the fulfillment of any of the defined legal conditions.

5. In the case of rendering the rejection judgment, concrete effects affecting various interests are caused. Among the effects that arise when rendering a rejection judgment are mainly: a) Determining the further termination of the main trial with the purpose of establishing whether the accusations against the accused are true or not, b) The detained defendant is released from detention on remand, i.e. it terminates any security measure imposed by the court; c) Clearly determined to address the costs of criminal proceedings; d) Addressing the issue of the property claim and e) Reducing some of the public expenditures.

6. According to the data used by the Basic Courts of Kosovo during the period 2015 - 2017 regarding the indictment filed for the commission of various criminal offenses 70550 persons have been tried in total, of whom 62311 accused adults were accused, while juvenile defendants there were 8239 people. As it turns out, the number of juvenile offenders judged is 54072 cases or $86.8 \%$ lower than the number of accused adult persons, which was in principle expected. The Basic Courts of Kosovo during the period involved in the research have issued a total of 4140 rejection judgments. Such judgments were most issued by Basic Court of Pristina 1123 of them, and the least, 234 rejection judgments were issued by the Basic Court of Mitrovica.

7. Out of the 100 studied rejection judgments, it results that in 54 cases they were rendered due to withdrawal of the indictment by the state prosecutor, in 27 cases due to the statutory limitation of criminal prosecution and in 19 cases due to amnesty and pardon. These data point to the fact that there is insufficient professionalism and an unsatisfactory update in Kosovo's judicial and prosecutorial system. Therefore, it is required by the institutional responsibilities to undertake concrete actions that enhance the performance of judges and prosecutors, including the necessity to carry out a vetting process in the entirety of bodies that constitute the criminal justice system in the country. 


\section{REFERENCES}

Literatures

DAMIR Kos, A verdict in criminal proceedings as a result of willing parties, pg. 7 ï 8 . Available at:http://www.vsrh.hr/custompages/static/hrv/files/dkos-

presuda_u_kaznenom_postupku_kao_rezultat.doc

HAJDARI Azem (2013), Criminal Procedure Law, General Part, "ILIRIA" College. Pristina.

HAJDARI Azem (2013), Criminal Procedure Law, Special Part, College "ILIRIA, Prishtina.

HAJDARI Azem (2015), Juvenile criminality in Kosovo, Lap Lambert Academic Publishing, Saarbrücken, Deutschland.

HAJDARI Azem (2015), Juvenile Criminality in Kosovo, Macrothink Institute, Issues in Social Science, 2015, Vol. 3 , No. 1.

HAJDARI Azem, Commentary, Criminal Procedure Code (2016), "FAMA" College, Pristina.

ISLAMI Halim., Hoxha Artan, Panda Ilir (2003). Criminal procedure, commentary. University of Tirana, Tirana.

MARINA Caril , PAJL ÍL Matko (2016), Basics of Criminal Procedure, Faculty of Law in Split, Split, 2016.

PAVIGíl Berislav, VUL KOVIĹ Milojko, VELIĹ Petar, RADOLOVIĹ Aldo (1998), Act on Criminal Procedure, with Commentary, Literature and Jurisprudense, Zagreb.

SAHITI Ejup, MURATI Rexhep, ELASHANI Xhevdet (2014), Criminal Procedure Code of the Republic of Kosovo, Commentary, Publication I, GIZ, Legal Reform Project in Kosovo, Pristina.

SAHITI Ejup. MURATI Rexhep (2013), Criminal Procedure Law, University of Prishtina "Hasan Prishtina", Prishtina.

FUNK T. Markus (2006), Kosovo trial skills handbook, United State, Department of Justice, Office of the Resident Legal Advisor, Pristina.

mLR L R N Mladen (2016), Reasoning of the Criminal Judgment as an Element of the Right to a Fair Trial, University of Belgrade, Beograd.

\section{Legislations}

Criminal Procedure Code, Code no. 04 / L - 123, Article 363. Available at: https://gzk.rksgov.net/ActDetail.aspx?ActID=2861

Criminal Procedure Law of Macedonia, Official gazette No. 150 from 18 November 2010. Available at: https://sherloc.unodc.org/res/cld/document/mkd/1996/criminal-procedure-code-of-the-republic-ofmacedonia-as-of-2010_html/FYROM_Criminal_procedure_code_as_of_2010_English.pdf

\section{Other sources}

Annual Reports of the Kosovo Judicial Council and Kosovo Agency of Statistics on the Work of Kosovo Courts for the period 2015 - 2017. Available at: http://www.gjyqesori-rks.org/sq/kjc/report/list/1, http://ask.rks-gov.net/sq/agjencia-e-statistikave-te-kosoves/sociale/jurisprudenca

Data on the Kosovo population from the Kosovo Agency of Statistics. Available at: http://ask.rks-gov.net/sq/agjenciae-statistikave-te-kosoves/sociale/regjistrimi-i-popullsise-dhe-banesave.

List of Basic Court Decisions. Available at: http://www.gjyqesori-rks.org/sq//courts/decision/list/3. 